uria (Meyer-Betz, 1911) and an association with alcohol overlooked or regarded as incidental. For example, Elek and Anderson (1953) described " paroxysmal paralytic myoglobinuria" in a woman after the ingestion of a "few gins," and more recently Schutta et al. (1969) reported the cases of three patients with "paroxysmal idiopathic myoglobinuria," all of whom were heavy drinkers.

So far as we are aware the above is the first example of the condition described in this country, but it seems possible that myopathy due to alcohol may be commoner than is generally realized, and a history of alcoholism in patients with a neuromuscular disorder should be considered as of possible aetiological significance.

We wish to thank Dr. A. Paton and Dr. J. Thompson for their help and advice. We are particularly grateful to Drs. A. L. Woolf and J. Haynes, and to Messrs. C. J. Morris, W, Edwards, and

\section{Recurrent Virus Meningitis}

British Medical fournal, 1969, 4, 786

Aseptic meningitis is a common clinical problem, but one patient having two separate attacks with different viruses is exceptional enough to be of interest. Gray, Moffatt, and Sangster (1969) described such an event in a patient who, having recovered from mumps meningitis in 1961, developed E.C.H.O. 30 meningitis in 1966. A review of the literature and correspondence with colleagues of wide experience have not revealed any further virologically proved examples of such double attacks. The following case history therefore seems worthy of report.

\section{CASE REPORT}

A 6-year-old boy, an only child, was admitted to Taunton Isolation Hospital on 26 July 1968 with a 24-hour history of headache, drowsiness, and some vomiting. The clinical picture was orfe of meningeal irritation; his cerebrospinal fluid (C.S.F.) contained 76 cells/cu.mm., mainly lymphocytes, but was otherwise normal. He made a rapid and complete recovery, being well enough to return home within a week. An E.C.H.O. virus type 6 was isolated from his faeces.

Ten months later he was readmitted, again having been unwell for about 24 hours, with headache and neck stiffness. On this occasion he was more severely ill and remained febrile for almost a week. The diagnosis of tuberculous meningitis had now to be entertained, since the C.S.F. contained 120 cells/cu.mm. (rising later to 550 ), $60 \%$ lymphocytes, a protein of $75 \mathrm{mg} . / 100 \mathrm{ml}$., and a sugar of $36 \mathrm{mg} / 100 \mathrm{ml}$; no organisms were seen on the film. His Mantoux $1 / 100$, however, was negative, his chest $x$-ray picture was clear, and no choroidal tubercles were seen on ophthalmoscopy. He remained alert and rational, and his electroencephalogram was normal ; chemotherapy was therefore withheld. Equivocal fullness of one parotid was overlooked; but during the second week his mumps complement fixation tests were reported as $V \cdot 1 / 10,240$ and $S \cdot 1 / 160$; his serum amylase was 210 units $/ 100 \mathrm{ml}$. (upper limit of normal 150). His mother then recalled contact with a child incubating mumps 19 days before admission. He was now recovering steadily,
R. Westhead of the Midland Centre for Neurosurgery and Neurology, Smethwick, for detailed investigations of muscle structure and function.

$$
\text { Medical Registrar }
$$$$
\text { E. T. O’BRIEN, L.R.C.P.I., }
$$$$
\text { House-physicia }
$$

P. Goldstraẇ, M.B., CH.B.,

Dudley Road Hospital, Birmingham 18.

\section{REFERENCES}

Ekbom, K., Hed, R., Kirstein, L., and Astrom, K. (1964). Archives of

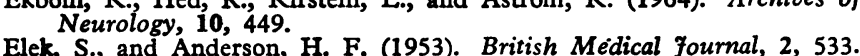

Elek, S., and Anderson, H. F. (1953). British Médical fournal, 2, 533.
Hed, R., Lundmark, C., Fahlgren, H., and Orell, S. (1962). Acta Medica Scandinavica, 171, 585 .

Klinkerfuss, G., Bleisch, V., Dioso, M. M., and Perkoff, G. T. (1967). Annals of Intermal Medicine, 67, 493.

Meyer-Betz, F. (1911). Deutsches Archiv für klinische Medizin, 101, 85 .

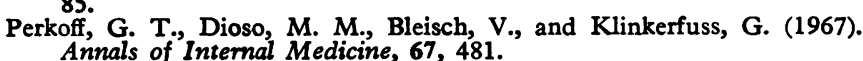
Schutta, H. S., Kelly, A. M., and Zacks, S. I. (1969). Brain, 92, 191. and soon returned home, resuming school attendance before the end of term. When reviewed in August 1969 he was physically fit, but was reported to be bad-tempered and easily upset. His mumps complement fixation tests had fallen to V.1/120 and S.1/40; the serum amylase was 85 units \% ; mumps virus had been grown from a throat swab, but not from the faeces or C.S.F. His serum proteins were normal, including electrophoresis of the immunoglobulins.

\section{Comment}

Recurrent bacterial meningitis is a well-recognized clinical problem, usually associated with structural or immunological anomalies. More than one attack of proved virus meningitis, however, seems a curious coincidence-presumably without such clinicopathological implications. Nevertheless, a challenging diagnostic and therapeutic predicament may be encountered in the individual patient. Careful separate assessment of each clinical episode is absolutely essential. The risk that a halftreated suppurative condition may masquerade as a "virus" meningitis must always be recalled (Brown, 1967), and tuberculous meningitis must be kept in mind, though fortunately this is now a clinical rarity (Anderson, 1964 ; Christie, 1969). The temptation to give ill-judged antibacterial therapy may be strong in a second meningitic illness, particularly if virological investigation of the first attack was incomplete and there is therefore past as well as present diagnostic uncertainty. The above case report illustrates the value of full virus studies (combined selectively with E.E.G. and other aids to exclude a space-occupying lesion) in clinical management.

The virological investigations were kindly performed by Drs. D. Tavaria, J. Pether, and Wynne Jones, of the Public Health Laboratory Service, Taunton.

\section{J. P. ANDERSON, M.D., M.R.C.P.ED., D.C.H. Isolation Hospital, Taunton, Somerset.}

\section{REFERENCES}

Anderson, J. P. (1964) British Medical fournal, 1, 1310. Brown, E. H. (1967) Postgraduate Medical fournal, 43, 418. Christie, A. B. (1969). In Infectious Diseases: Epidemiology and Clinical Practice, chap XVII, Edinburgh, Livingstone. Gray, J. A., Moffatt, M. A. J., and Sangster, G. (1965). Scottish Medical fournal, 14, 234. 